\title{
ВПЛИВ МУЗИЧНОЇ ТЕРАПІЇ НА ЗМЕНШЕННЯ ІНТЕНСИВНОСТІ БОЛЮ ПІСЛЯ ОПЕРАЦЙННОГО ВТРУЧАННЯ У ДІТЕЙ
}

\author{
Ю. В. Іванович, М. І. Кінаш \\ Львівська обласна дитяча клінічна лікарня “ОХМАТДИТ» \\ ДВНЗ «Тернопільський державний медичний університет \\ імені І. Я. Горбачевського МОЗ Украӥни"
}

У статті подано результати спостережень впливу музичної терапії на вираження інтенсивності післяопераційного болю у дітей. Проаналізовано інформацію про вплив музичної терапії як одного 3 нефармакологічних методів лікування болю.

\section{EFFECT OF MUSICAL THERAPY TO REDUCE PAIN AFTER SURGERY IN CHILDREN}

\author{
Y. V. Ivanovych, M. I. Kinash \\ Lviv Oblast Children's Clinical Hospital OKHMATDYT \\ I. Horbachevsky Ternopil State Medical University
}

The article presents the results of observations of the influence of musical therapy on postoperative pain in children. The information on the influence of musical therapy as one of the non-pharmacological methods of pain management is analyzed.

Вступ. Біль - це не тільки сенсорна модальність, а й емоційне переживання. Деякі дослідження показали, що найефективнішим підходом усунення післяопераційного болює поєднане застосування медикаментозних та немедикаментозних методів його лікування. Отже, використання немедикаментозних методів лікування болю може ефективно знизити його інтенсивність та зменшити дозу седативних препаратів перед операційним втручанням, а також зменшити дози анальгетиків після операційного втручання. Управління болем є важливим аспектом у лікуванні дітей.

Окрім фармакологічних варіантів лікування болю, музична терапія також має позитивний вплив на зменшення інтенсивності болю. Багато медичних втручань, спрямованих на допомогу дітям, заподіює їм біль і страждання, що можуть мати довготривалі негативні наслідки. Сучасна медична сестра повинна мати не тільки хорошу технічну підготовку, але й навички творчого підходу до пацієнта як особистості, а не як нозологічної одиниці [1].

У багатьох країнах світу музикотерапію використовують з лікувальною метою усунення болю. В Україні

(c) Ю. В. Іванович, М. І. Кінаш, 2018 цей метод поки що належить до новітніх, передовсім, медичних практик. Американська медицина вперше почала експериментувати з терапевтичним використанням музики наприкінці XIX століття. У 90-х роках невропатолог Корнінг повідомив про те, що музика Вагнера й інших композиторів-романтиків знижує рівень хворобливих думок і підсилює дію медичних препаратів. У 1918 р. Колумбійський університет розробив перший курс «Музикотерапії», який призначався для солдатів, які отримали поранення під час Першої світової війни. У 1930 і 1940 роках використання музики і звуку для зменшення та послаблення больових відчуттів почали застосовувати в стоматології та хірургії. У США, Великій Британії, Італії та Франції музикотерапія визнана офіційним засобом відновлення пацієнтів у рамках державної системи страхової медицини [2]. «Музика ставить нас у кращий настрій, коли ми знаходимось в кращому настрої, мозок вивільняє нейрохімічні речовини та гормони, які стимулюють імунну функцію», - Dr. Daniel J. Levilin, невролог з університету Макгілла в Монреалі [3]. Дослідження університету Брунеля та Лондонського університету Марії, паказали, що у хворих, 
яким дозволили перед операційним втручанням насолоджуватись улюбленою музикою, зареєстрували зменшення рівня болю на два бали за шкалою від одного до десяти. Ці пацієнти потребували менше медикаментів, щоб почувати себе комфортно [4]. Доктор Катрін Медс з Університету Брунеля, яка є співавтором цього дослідження, заявила, що їх результати можуть бути корисними в практичній медицині для хворих 3 інтенсивним болем різного генезу, зокрема післяопераційний біль: «Музика - це неінвазивне, безпечне та дешеве втручання, яке повинно бути доступним для всіх, хто проходить операцію» [5]. Варто зазначити, що не відповідна музика може загострювати відчуття болю у пацієнта. Ефекти музичної терапії можуть допомогти полегшити біль та зменшити стрес і тривогу пацієнта, що призводить до фізіологічних змін, у тому числі поліпшення дихання, зниження кров'яного тиску, поліпшення серцевого викиду і зниження частоти серцевих скорочень, розслаблення м'язового напруження. Реакції на музику, виміряних за допомогою сканувань головного мозку, електричних активностей і змін у зіницях, показують значне скорочення тривалості та інтенсивності болю й тривоги [6].

Для удосконалення лікування післяопераційного болю медичні сестри повинні вміти впроваджувати музикотерапію як нефармакологічний метод лікування болю.

Декілька основних порад, які мають використовувати медичні сестри у бесіді з пацієнтами та їхніми родичами:

- підкреслити у розмові з пацієнтом та/або його родичами, що немедикаментозна терапія не замінить анальгетики;

- вміти оцінити досвід і ставлення пацієнта до немедикаментозного знеболювання;

- з'ясувати, чи пацієнт використовував немедикаментозні методи для зменшення болю, чи були вони успішними, і з якими проблемами, якщо були такі, довелося стикнутися;

- надати пацієнтові та членам його сім'ї відповідні освітньо-інформаційні матеріали [7].

Мета дослідження - ознайомити пацієнтів та їхніх родичів із музикотерапією як одним із немедикаментозних методів лікування болю. З'ясувати ефективність використання музичної терапії у боротьбі з післяопераційним болем.

Основна частина. Під спостереженням перебувало 60 пацієнтів віком від 1 до 14 років, які перебували на стаціонарному лікуванні у відділенні інтенсивної терапії Львівської обласної дитячої клінічної лікарні «ОХМАТДИТ». Серед обстежуваних переважали хлопчики - 40 (66,7 \%) осіб, дівчаток було 20 (33,3\%). Серед них жителі сільської місцевості становили 45 (75 \%) пацієнтів, з них 35 (58,3 \%) хлопчиків, 10 (16,7 \%) дівчаток, жителі міста, відповідно, 15 (25 \%) осіб, серед них дівчаток було 10 (16,7\%), хлопчиків 5 (8,3 \%). Всі діти отримували планові та ургентні операційні втручання. 3 приводу металоостеосинтезу операційні втручання проведені у 30 (50 \%) осіб, тонзилектомії у 15 (25\%) пацієнтів, апендектомії, відповідно, у 15 (25 \%) хворих. Після операційних втручань усі діти були переведені до післяопераційних палат. Дітей поділили на дві групи по 30 осіб у кожній. У першій групі перебувало 20 (66,7 \%) дітей жителів сільської місцевості, серед них переважали хлопчики 15 (75 \%), дівчаток було 5 (25 \%), а також 10 (33,3 \%) жителів міста, серед них дівчаток було 7 (70 \%), а хлопчиків 3 (30 \%). До другої групи увійшли 22 хлопчики (73,3 \%), з них 20 (90,9 \%) жителі сільської місцевості, 2 (9,1 \%) жителі міста, а також 8 дівчаток $(26,7 \%)$, серед них 5 (62,5 \%) жителів сільської місцевості та 3 (37,5 \%) осіб із міської місцевості. У першій групі пацієнти, відповідно до своїх бажань, слухали музику та аудіокниги. Друга група - контрольна, хворі, які не слухали музики та аудіокниг. Упродовж 72 год діти першої групи прослуховували різні варіанти музики та аудіокниг. Пацієнти, які прослуховували музику, обирали веселі дитячі пісні українських та зарубіжних виконавців, а також класичну музику. Особи, які прослуховували аудіокниги, обирали українські народні та зарубіжні казки, у тому числі «Хоббіт», «Аліса в країні чудес». Перед проведенням операційного втручання діти мали змогу обрати твори, які зацікавили їх. Медичні сестри оцінювали показники болю за шкалою VAS та FLACC.

У результаті дослідження, у 30 дітей першої групи, які слухали музику та аудіокниги, спостерігали зниження інтенсивності болю на 1 бал за 10-бальною шкалою VAS та FLACC у першу добу, порівняно з контрольною групою, на другу та третю добу, відповідно, на 2 бали. На противагу цьому пацієнти в контрольній групі не зазнали жодних ефектів від прослуховування тиші. Швидше заспокоєння від музикотерапії спостерігали у дітей в ранкові години з 8:00-10:00, та у вечірній час з 20:00-23:00, кращий ефект від музикотерапії відзначали у жителів сільської місцевості, жителі міста досягали бажаного ефекту повільніше. Після виписування зі стаціонару пацієнти практикували прослуховування улюбленої музики та аудіокниг вдома, що сприяло 
швидшому зникненню больових відчуттів та загоєнню післяопераційної рани внаслідок позитивних емоцій.

Висновки. 1. У результаті дослідження виявлено позитивний вплив музичної терапії на зменшення інтенсивності болю у дітей в післяопераційний період, порівняно з контрольною групою, пацієнти, якої не слухали музики та аудіокниг.

2. Використання немедикаментозних методів лікування болю дасть можливість ефективно знизити

\section{СПИСОК ЛІТЕРАТУРИ}

1. Кривучко І. А. Медсестринство в хірургії : навч. посіб. / І. А. Кривучко, В. В. Чугай, Н. М. Гончарова. - Харків, 2017. - 5 c.

2. URL : http://gk-press.if.ua/x4089/

3. URL : https://www.cbsnews.com/news/want-to-reducepostoperative-pain-get-into-the-groove/

4. URL : https://www.telegraph.co.uk/news/health/ news/11798619/Listening-to-music-before-and-aftersurgery-relieves-pain-and-anxiety.html інтенсивність больових відчуттів та зменшити дозу седативних препаратів перед операційним втручанням, i/або зменшити дози анальгетиків після операційного втручання.

3. Для покращення лікування післяопераційного болю можна рекомендувати медичним сестрам відділень інтенсивної терапії для дітей впроваджувати музикотерапію як нефармакологічний метод лікування болю.

5. URL : http://www.factmag.com/2015/08/13/musicsurgery-reduces-pain-speeds-recovery/

6. URL : http://repo.knmu.edu.ua/bitstream/123456789/ 17740/1/2.pdf

7. URL : http://intranet.tdmu.edu.ua/data/kafedra/ internal/magistr/classes_stud/\%D

Отримано 03.04.18 